\title{
Soil Chemical and Physical Properties Associated with Suppression of Take-all of Wheat by Trichoderma koningii
}

\author{
Brion K. Duffy, Bonnie H. Ownley, and David M. Weller
}

First author: Department of Plant Pathology, Washington State University; and second and third authors: Agricultural Research Service, U.S. Department of Agriculture, Pullman, WA 99164-6430.

Current address of B. K. Duffy: Phytopathology Group, Institute of Plant Sciences, Swiss Federal Institute of Technology, Universitätstrasse 2, CH-8092 Zürich, Switzerland; and B. H. Ownley: Department of Entomology and Plant Pathology, Institute of Agriculture, University of Tennessee, Knoxville 37996.

Accepted for publication 11 August 1997.

\begin{abstract}
Duffy, B. K., Ownley, B. H., and Weller, D. M. 1997. Soil chemical and physical properties associated with suppression of take-all of wheat by Trichoderma koningii. Phytopathology 87:1118-1124.

Trichoderma koningii, originally isolated from a take-all-suppressive soil in Western Australia, has been shown to protect wheat against takeall disease and increase grain yield in field trials in Australia, China, and the United States. However, within a region, the level of protection provided by $T$. koningii can dramatically vary between field sites. We evaluated suppression of take-all by this fungus in eight silt loams from the Pacific Northwest of the United States and the influence of 21 abiotic soil parameters on biocontrol activity. While T. koningii significantly

activity was positively correlated with iron, nitrate-nitrogen, boron, copper, soluble magnesium, and percent clay, and negatively correlated with soil $\mathrm{pH}$ and available phosphorus. Principal component factor analysis using these eight variables resulted in a three-component solution that accounted for $95 \%$ of the variation in disease rating. Least squares regression analysis $\left(R^{2}=0.992\right)$ identified a model that included nitrate-nitrogen, soil $\mathrm{pH}$, copper, and soluble magnesium, and described the variance in take-all suppression by $T$. koningii. Potential applications of these results include amending soil or inoculants with beneficial factors that may be lacking in the target soil and customizing biocontrol treatments for sites that have parameters predictive of a favorable environment for disease suppression.
\end{abstract} increased plant growth and reduced disease severity in all eight silt loams, the level of protection varied significantly among the soils. Disease suppression was not associated with the conduciveness of a soil to take-all, but rather to the supportiveness of a soil to biocontrol activity. Biocontrol
Additional keywords: biological control, edaphic parameters, Gaeumannomyces graminis var. tritici, soilborne pathogen, trace minerals, Triticum aestivum.
Take-all, caused by the soilborne ascomycete Gaeumannomyces graminis (Sacc.) von Arx \& D. Olivier var. tritici J. C. Walker, is one of the most economically important crown and root rot diseases of wheat worldwide. Biological control of take-all has been investigated intensively, largely because of a lack of commercially available alternatives, especially in reduced-tillage cropping systems that aggravate the disease but are increasingly encouraged to promote soil conservation (8). In the Pacific Northwest of the United States, after continuous cropping to wheat for several seasons, a natural decline of take-all develops that has been attributed to a gradual increase in populations of antagonistic fluorescent Pseudomonas spp. (7). Seed applications of bacterial isolates that produce the antibiotics 2,4-diacetylphloroglucinol or phenazine-1-carboxylate increase grain yield, on average, about 10 to $20 \%$ in fields where take-all is the predominant limiting factor $(6,45)$. In Western Australia, take-all decline has been attributed to populations of Trichoderma spp. that suppress the pathogen's saprophytic, as well as parasitic, activity (38). Soil treatment with T. koningii Oudem., the most abundant antagonist in these suppressive soils, reduced

Corresponding author: B. K. Duffy; E-mail address: brion.duffy@ipw.agrl.ethz.ch

Mention of a trademark or proprietary product does not constitute a guarantee or warranty of the product by the U.S. Department of Agriculture nor does it imply approval to the exclusion of other products that may also be suitable.

Publication no. P-1997-0917-01R

This article is in the public domain and not copyrightable. It may be freely reprinted with customary crediting of the source. The American Phytopathological Society, 1997. saprophytic growth of G. graminis var. tritici (38) and increased survival of wheat seedlings by about $50 \%$ (13) in greenhouse experiments with natural soil; grain yield was increased about $10 \%$ in three out of six field trials (32). A strain of T. koningii originally isolated from a suppressive soil in Western Australia reduced takeall severity and increased yield as much as $65 \%$ when added to the seed furrow in field trials in Washington State, United States (16).

Both the take-all pathogen and indigenous antagonists are sensitive to soil $\mathrm{pH}$ and mineral nutrition. Microbially mediated takeall decline occurs after three wheat crops in slightly acidic soils of $\mathrm{pH}$ 5.5, but is delayed until the sixth or seventh crop when soil $\mathrm{pH}$ is elevated to 7.0 by liming (7). Ammonium-nitrogen fertilizers reduce rhizosphere $\mathrm{pH}$ of wheat and increase the proportion of rhizosphere bacteria that are antagonistic to $G$. graminis var. tritici, resulting in less take-all; the reverse is true of nitrate-nitrogen fertilizers $(33,41)$. Similarly, the take-all-suppressive activity of indigenous populations of Trichoderma spp. is increased by soil acidification with ammonium fertilizers, and this effect is lost with liming (38). Ammonium-chloride is superior to ammonium-sulfate, because chloride lowers the plant water potential and results in greater take-all-suppressive activity of antagonistic rhizosphere bacteria than occurs on roots of wheat fertilized with ammoniumsulfate (7). An adequate supply of micronutrients such as copper, iron, manganese, and zinc alleviates take-all, and their increased availability under acidic soil conditions is due, in part, to the metabolic activity of certain indigenous microorganisms. Huber (24) suggested that oxidation of manganese to $\mathrm{Mn}^{4+}$ by the pathogen decreases availability of this micronutrient to wheat, leading to increased take-all; but this effect is reversed by soil acidification, because it favors rhizosphere populations of bacteria that reduce 
manganese to $\mathrm{Mn}^{2+}$, a form more available to the plant. Managing indigenous populations of microorganisms for reliable take-all control, however, is not always feasible, since economic pressures and soil conservation efforts in the Pacific Northwest and other wheat-growing areas often discourage cultural practices that can have a beneficial effect on the antagonistic soil microflora. Furthermore, germinal populations of antagonistic microbes amenable to selection may be nonexistent in some soils.

The commercialization of biocontrol agents for take-all has been delayed by inconsistent performance among sites and years (46). Understanding the influence of soil properties on the diseasesuppressive activity of introduced microorganisms should facilitate tailoring biocontrol agents for use in fields where biocontrol activity is maximized (6). For example, the take-all-suppressive activity of $P$. fluorescens biocontrol strain 2-79 was positively associated with soil $\mathrm{pH}$, percent sand, ammonium-nitrogen, sodium, sulfate-sulfur, and zinc concentrations (29). The addition of zinc as an EDTA complex to a soil low in zinc improved the suppression of take-all by 2-79 (46). The effect of zinc is likely due, in part, to stimulation of phenazine production by 2-79 $(39,46)$. Inhibition of $G$. graminis var. tritici by $2-79$ in vitro is optimal at $\mathrm{pH}$ 6.0, and biocontrol activity is favored at a soil $\mathrm{pH}$ between 5.6 and $7.6(30)$. Phenazine accumulation in vitro is likewise favored at $\mathrm{pH} 6.5$ to 7.5 (40). Similar findings have been reported for another model biocontrol strain, P. fluorescens CHA0, that was originally isolated from a Swiss soil naturally suppressive to tobacco black root rot. This and similar Swiss suppressive soils typically contain more iron and zinc than do conducive soils (11). Iron availability has since been found to be critical for hydrogen cyanide biosynthesis and the biocontrol activity of CHA0 (11), while zinc favors production of the antibiotics 2,4-diacetylphloroglucinol and pyoluteorin (15). Zinc also improves the stability of gacA and apdA genes that regulate traits important to $\mathrm{CHA} 0$ biocontrol activity including production of hydrogen cyanide and antibiotics (14). Targeting these bacteria for soils with adequate concentrations of key minerals or applying them in formulations with mineral amendments may improve their performance.
Little is known about the influence of minerals and other soil factors on the biocontrol activity of Trichoderma spp. The objectives of this study were to first evaluate the take-all-suppressive activity of T. koningii in field soils representative of the wheat-growing region in the Pacific Northwest of the United States, and then to identify abiotic edaphic parameters that are positively and negatively associated with the biocontrol activity of $T$. koningii in these soils. Such information will be useful (i) in selecting sites where T. koningii can be expected to perform optimally; (ii) in developing formulations that enhance biocontrol; (iii) and perhaps in indicating factors that favor mechanisms involved in the biocontrol activity of this strain such as antibiotic and enzyme biosynthesis.

\section{MATERIALS AND METHODS}

Fungi and inoculum production. The biocontrol activity of $T$. koningii was demonstrated previously in a Puget silt loam from Mt. Vernon, WA (16). The fungus originally was isolated from a takeall-suppressive soil in Western Australia. Production of a variety of antibiotic compounds including the novel compound 4,8-dihydroxy2-(1-hydroxyheptyl)-3,4,5,6,7,8-hexahydro-2H-1-benyopyran-5-one is thought to contribute to its biocontrol activity (38). For longterm storage, T. koningii was maintained on colonized rye grass seed at $-20^{\circ} \mathrm{C}$. For each trial, fresh inoculum of T. koningii and $G$. graminis var. tritici was prepared as previously described (16). Briefly, fungi were grown on plates of dilute $1 / 5$-strength potato dextrose agar for 2 to 7 days at $22^{\circ} \mathrm{C}$. Autoclave-sterilized rye grass seed and oat kernels (250 g of seed or kernels and $250 \mathrm{ml}$ of distilled water per liter flask) were inoculated with two plates of $T$. koningii or G. graminis var. tritici, respectively, and incubated in light at 21 to $25^{\circ} \mathrm{C}$ until completely colonized ( 2 weeks for $T$. koningii and 4 weeks for G. graminis var. tritici). Inoculum was air-dried and stored at $4^{\circ} \mathrm{C}$. Just prior to use, T. koningii inoculum was reduced to individual seeds and G. graminis var. tritici inoculum was ground in a blender and particles of 0.25 to $0.5 \mathrm{~mm}$ were collected (16). A mixture of four virulent strains of G. gra-

TABLE 1. Chemical and physical properties of silt loams

\begin{tabular}{|c|c|c|c|c|c|c|c|c|}
\hline \multirow[b]{2}{*}{ Property } & \multicolumn{8}{|c|}{ Soil $^{\mathrm{a}}$} \\
\hline & RSL & PuSL & LSL & TSL & WSL & WaSL & HSL & SSL \\
\hline \multicolumn{9}{|l|}{ Major element $(\mu \mathrm{g} / \mathrm{g})$} \\
\hline Boron & 0.18 & 0.53 & 0.36 & 0.31 & 0.36 & 0.14 & 0.25 & 0.18 \\
\hline Nitrogen- $\mathrm{NH}_{4}$ & 3.6 & 2.5 & 6.5 & 2.7 & 5.2 & 2.9 & 4.5 & 2.2 \\
\hline Nitrogen- $\mathrm{NO}_{3}$ & 29.6 & 160.0 & 145.0 & 12.1 & 108.0 & 47.7 & 20.2 & 112.0 \\
\hline Phosphorus (available) & 34.2 & 5.4 & 4.6 & 12.6 & 6.6 & 4.9 & 15.5 & 8.2 \\
\hline Potassium (available) & 186.0 & 158.0 & 288.0 & 224.0 & 185.0 & 528.0 & 536.0 & 198.0 \\
\hline Sulfur- $\mathrm{SO}_{4}$ & $<2.0$ & 2.0 & 6.0 & 5.0 & 6.0 & 5.0 & 2.0 & $<2.0$ \\
\hline \multicolumn{9}{|l|}{ Soluble cations (mM+/liter) } \\
\hline Calcium & 4.7 & $<0.1$ & $<0.1$ & 1.0 & 8.1 & 1.9 & 3.1 & 9.7 \\
\hline Magnesium & 1.0 & 4.5 & 4.1 & 0.4 & 2.0 & 1.2 & 1.3 & 5.4 \\
\hline Potassium & 0.1 & 1.2 & 1.7 & 0.3 & 0.9 & 1.6 & 1.5 & 1.0 \\
\hline Sodium & 0.8 & 1.3 & 1.2 & 1.0 & 0.6 & 3.3 & 0.4 & 1.4 \\
\hline \multicolumn{9}{|l|}{ DTPA extractable $(\mu \mathrm{g} / \mathrm{g})^{\mathrm{b}}$} \\
\hline Copper & 0.9 & 3.0 & 1.0 & 1.2 & 0.6 & 0.8 & 0.7 & 1.8 \\
\hline Iron & 5.0 & 64.7 & 62.2 & 35.6 & 54.1 & 23.2 & 22.3 & 52.3 \\
\hline Manganese & 16.1 & 44.2 & 110.0 & 93.9 & 104.0 & 71.6 & 99.9 & 61.5 \\
\hline Zinc & 1.7 & 1.4 & 3.4 & 3.1 & 2.8 & 1.6 & 2.3 & 2.8 \\
\hline $\mathrm{pH}$ & 8.3 & 5.8 & 4.9 & 6.5 & 4.6 & 6.1 & 6.6 & 6.0 \\
\hline Organic matter $(\%)$ & 1.35 & 2.31 & 4.19 & 2.86 & 3.66 & 1.53 & 3.15 & 1.31 \\
\hline $\mathrm{CEC}\left(\mathrm{cM}^{+} / \mathrm{kg}\right)^{\mathrm{c}}$ & 11.8 & 12.3 & 22.2 & 20.7 & 18.6 & 14.2 & 18.4 & 12.8 \\
\hline Soil water ratio $(\mathrm{g}: \mathrm{ml})$ & $50: 25$ & $50: 30$ & $50: 25$ & $50: 30$ & $50: 30$ & $50: 25$ & $50: 30$ & $50: 25$ \\
\hline \multicolumn{9}{|c|}{ Particle size distribution $(\%)$} \\
\hline Clay & 6.8 & 20.8 & 12.8 & 18.8 & 24.8 & 10.8 & 8.8 & 10.8 \\
\hline Sand & 34.8 & 22.8 & 34.8 & 22.8 & 18.8 & 34.8 & 32.8 & 32.8 \\
\hline Silt & 58.4 & 56.4 & 52.4 & 58.4 & 56.4 & 54.8 & 58.4 & 56.4 \\
\hline
\end{tabular}

${ }^{a}$ Soils were classified as Ritzville silt loam (RSL), Puget silt loam (PuSL), Larkin silt loam (LSL), Thatuna silt loam (TSL), Woodburn silt loam (WSL), Walla

Walla silt loam (WaSL), Hermiston silt loam (HSL), and Shano silt loam (SSL).

${ }^{\mathrm{b}}$ Diethylene triamine penta-acetic acid.

c Cation-exchange capacity. 
minis var. tritici was used to minimize possible effects from variation in the response of the pathogen to the biocontrol agent.

Soils. Eight soils representative of those in the wheat-growing region of the Pacific Northwest were used. Hermiston, Larkin, Ritzville, Thatuna, Puget, Shano, Woodburn, and Walla Walla silt loams were collected from sites in Washington State near Dusty, Fairfield, Lind, Pullman, Mt. Vernon, and Quincy, and sites in Oregon State near Corvallis and Pendleton, respectively. Chemical and physical properties for the soils were determined by the University of Idaho Soil Testing Service, Moscow (Table 1). Soils of generally similar texture were selected to increase the sensitivity of our analysis of these factors and reduce the influence of other physical factors such as water-holding capacity, air-filled porosity, and pore density that may also influence biocontrol. Soils were col-
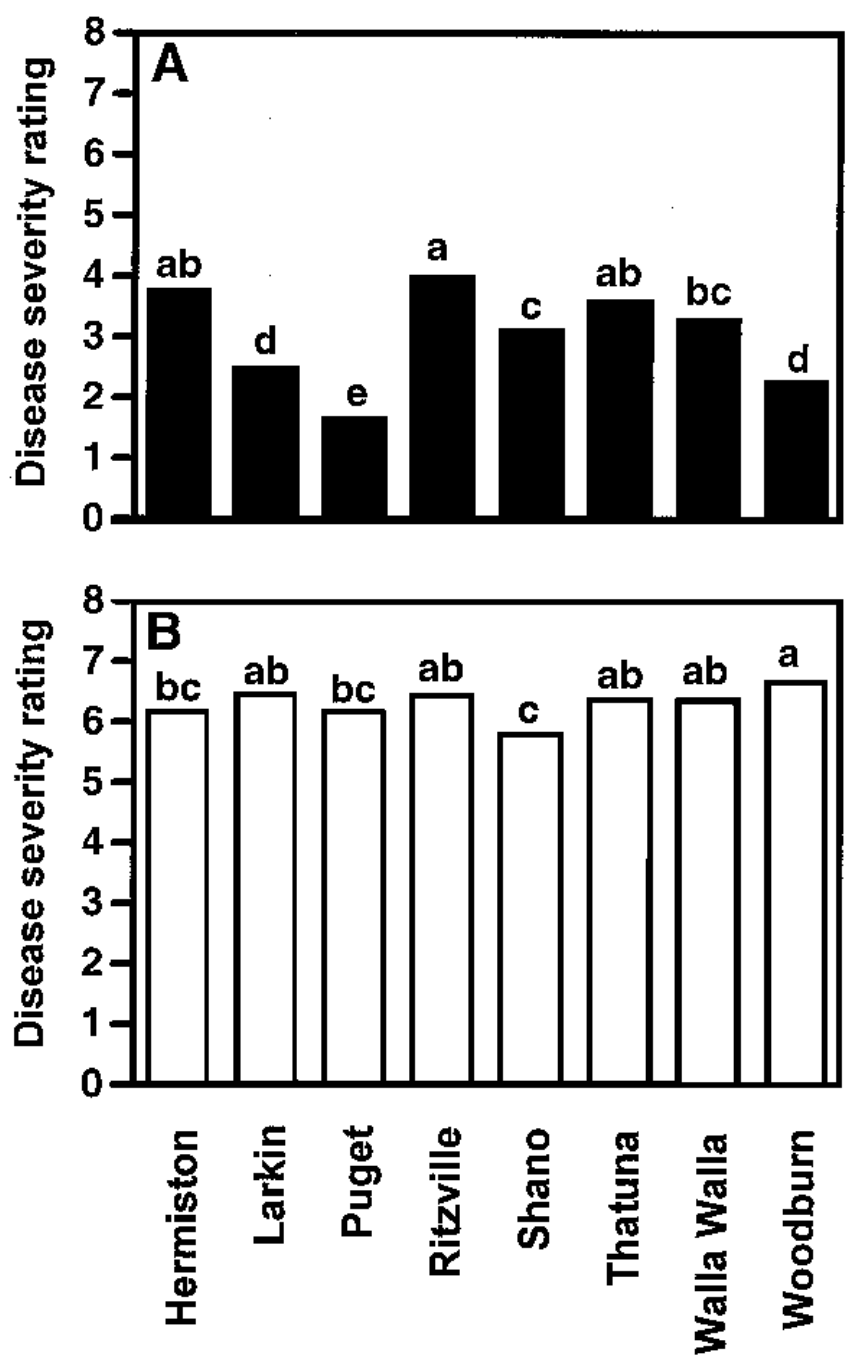

Fig. 1. Influence of soil type on $\mathbf{A}$, take-all development and $\mathbf{B}$, disease suppression by Trichoderma koningii. Eight silt loams representative of soils in the wheat-growing region of the Pacific Northwest of the United States were selected. Soils were steam-treated prior to use $\left(30 \mathrm{~min}\right.$ at $\left.94^{\circ} \mathrm{C}\right)$. Inoculum of T. koningii and the pathogen were added to the soil at 1 and $0.45 \%$ (wt/wt), respectively. Seed of spring wheat cv. Fielder were coated with dilute $0.5 \%$ methylcellulose. After 3 to 4 weeks of growth, plants were evaluated for takeall on a scale of 0 to 8 (28). Treatments were arranged in a split plot design. The soil type $\times$ soil treatment interaction was significant $(P \leq 0.0001)$. Further analysis of the interaction was performed using Fisher's protected least significant difference test $(P=0.05)$ on the response to the soil treatment. Bars with at least one letter in common are not significantly different at $\mathbf{A}, P=0.0399$ for the disease control and $\mathbf{B}, P \leq 0.0001$ for the biocontrol treatment. For each soil, disease severity rating was significantly $(P \leq 0.0001)$ reduced by $\mathbf{A}, T$. koningii soil treatment compared with $\mathbf{B}$, nontreated soil. lected from the upper $30 \mathrm{~cm}$ of the profile. Before use, soils were sieved $(2.0-\mathrm{mm} \mathrm{mesh})$, steam-treated $\left(30 \mathrm{~min}\right.$ at $\left.94^{\circ} \mathrm{C}\right)$, and allowed to air-dry for 2 days.

Evaluation of take-all suppression. Tube assays were conducted in the growth chamber as previously described $(16,30)$. Inoculum of $T$. koningii and $G$. graminis var. tritici were mixed into the soil at a rate of 1 and $0.45 \%$, respectively (based on soil dry weight). Plastic tubes $(2.5-\mathrm{cm}$ diameter $\times 16.5-\mathrm{cm}$ long), held upright in racks (200 per rack), were filled with a $6.5-\mathrm{cm}^{3}$ layer of sterile vermiculite followed by a $15-\mathrm{cm}^{3}$ layer of soil infested with G. graminis var. tritici alone or together with $T$. koningii. Each tube received $10 \mathrm{ml}$ of water with metalaxyl $(0.075 \mathrm{~g}$ of wettable powder per liter of tap water; Novartis Limited, Greensboro, NC) to suppress indigenous Pythium spp. Two surface-disinfested spring wheat seeds (cv. Fielder) were placed on the soil surface in each tube and covered with a $5-\mathrm{cm}^{3}$ layer of noninfested soil and a $5-\mathrm{cm}^{3}$ layer of sterile vermiculite. After planting, each tube received $5 \mathrm{ml}$ of tap water. Racks were covered with clear plastic, incubated at 20 to $25^{\circ} \mathrm{C}$ for 2 days to improve seedling emergence, and then transferred to a growth chamber $\left(15^{\circ} \mathrm{C}\right.$ with a 12 -h photoperiod). After emergence, plants were watered twice weekly with $5 \mathrm{ml}$ of dilute (1/3-strength) Hoagland's solution (macroelements only) (30). After 3 to 4 weeks of growth, plants were harvested, roots were washed free of soil, and shoot heights were measured. Take-all severity was rated on a scale of 0 to 8 as previously described by Ownley et al. (30) in which $0=$ no visible symptoms, $1=<10 \%$ roots black, $2=10$ to $25 \%$ roots black, $3=25$ to $50 \%$ roots black, $4=50$ to $100 \%$ roots black, $5=$ all roots with lesions and lesions at base of stem, $6=$ lesions moving up the stem, $7=$ plant chlorotic and severely stunted, and $8=$ plant dead or nearly so.

The experiment was arranged as an $8 \times 2$ factorial in a split plot design with eight soil types (main plot) and two soil treatments (nontreated control or soil amended with T. koningii) (subplot). Each treatment consisted of 10 seedlings (five tubes with two seedlings each) and was replicated six times. The experiment was repeated once. Main effects and interactions were analyzed for significance with the general linear models procedure of SAS, version 6 (Statistical Analysis Systems Institute, Cary, NC). Where appropriate, main effects and interactions were further analyzed using Fisher's protected $(P=0.05)$ least significant difference test. The relationship between the conduciveness of a soil to take-all and the biological control activity of $T$. koningii in that soil was tested using SAS correlation analysis (Pearson option).

Identification of soil parameters involved in biocontrol. We applied principal component factor (PCF) analysis (Varimax rotation) to identify which of 21 soil chemical and physical properties that were measured were positively or negatively interrelated with the take-all suppressiveness of $T$. koningii in these eight silt loams. PCF analysis is an investigative tool useful for identifying patterns of interrelated variables with the aim of selecting a reduced number of variables for further study (26). A preliminary PCF analysis was used to select properties related to disease rating (SAS, version 6). These selected properties were included in a final anal-

TABLE 2. Principal component factor analysis (Varimax rotation) of disease rating of wheat treated with Trichoderma koningii and soil properties ${ }^{\mathrm{a}}$

\begin{tabular}{lccc}
\hline Soil property & Component 1 & Component 2 & Component 3 \\
\hline Disease rating & -0.97 & $\mathrm{NS}$ & $\mathrm{NS}$ \\
$\mathrm{pH}$ & -0.81 & 0.50 & $\mathrm{NS}$ \\
Phosphorus (available) & -0.77 & 0.35 & 0.35 \\
Nitrate-nitrogen & 0.91 & $\mathrm{NS}$ & $\mathrm{NS}$ \\
Boron & 0.79 & $\mathrm{NS}$ & 0.54 \\
Copper & 0.61 & 0.64 & $\mathrm{NS}$ \\
Iron & 0.97 & $\mathrm{NS}$ & $\mathrm{NS}$ \\
Percent clay & 0.69 & -0.48 & 0.47 \\
Magnesium (soluble) & 0.73 & 0.53 & -0.39
\end{tabular}

a Loading values greater than, or equal to, the absolute value 0.35 indicates significant interrelatedness. NS $=$ not significant. 
ysis to develop the principal component solution that best explained the covariance among disease rating and soil properties. Loading values greater than, or equal to, the absolute value of 0.35 indicated significant interrelationships among variables within a principal component. The number of soil properties influencing biocontrol was further narrowed using least squares regression analysis to identify a model that included the least number of properties and best described variation in disease rating (28). Interactions among soil properties were evaluated using SAS correlation procedures (Pearson option). Correlation, regression, and PCF analyses were performed on pooled data.

\section{RESULTS}

Take-all suppression. Results for disease severity rating were similar in the two trials, and data were pooled for final analysis after confirming homogeneity of variances with an $F$ test. Both of the main effects (soil type and soil treatment) and the interaction were significant $(P \leq 0.0001)$. This interaction was further analyzed based on the response to each main effect.

In all eight silt loams, $T$. koningii significantly $(P \leq 0.0001)$ reduced the severity of take-all as compared with the nontreated control inoculated with only the pathogen (data not shown). Disease suppression by $T$. koningii significantly $(P \leq 0.0001)$ varied among the soils. For example, Puget silt loam supported the greatest decrease in disease severity rating, from 6.2 for the nontreated control to 1.6 for the T. koningii treatment (Fig. 1A). In contrast, Ritzville silt loam supported a reduction in disease severity rating from 6.5 to 4.0 (Fig. 1A). In the absence of T. koningii, disease ratings varied slightly but significantly $(P=0.0399)$ among soils (Fig. 1B); disease severity ratings ranged from a low of 5.8 in the Shano silt loam to a high of 6.7 in the Woodburn silt loam.

There was no correlation between the conduciveness of a given soil to take-all and the biocontrol activity of $T$. koningii in that soil. For example, Puget silt loam was among the least conducive soils for take-all, but was the most favorable soil for biocontrol activity (Fig. 1). In contrast, Woodburn silt loam was the most disease conducive soil, but the second most favorable soil for biocontrol.

Results for shoot height were similar in both trials; however, experimental variances were not homogenous according to an $F$ test, and data for each trial were analyzed independently. In neither trial was the soil $\times$ treatment interaction significant nor was the soil main effect significant. Over all soils, T. koningii significantly increased shoot height from 10.9 to $13.1 \mathrm{~cm}$ in the first trial and from 10.1 to $13.9 \mathrm{~cm}$ in the second trial compared with the nontreated controls $(P \leq 0.0001$ for both trials). In each of the eight soils, shoot height was increased with $T$. koningii amend- ment; the greatest increases relative to the nontreated controls were observed in Puget silt loam and Woodburn silt loam (36.4 and $38.5 \%$ increase in the first trial and 26.1 and $23.2 \%$ increase in the second trial, respectively).

Association of soil factors with biocontrol activity. Preliminary PCF analysis indicated that eight of the initial 21 soil properties were significantly interrelated with take-all disease rating. Soil variables unrelated to disease rating were omitted from the final PCF analysis. The final PCF analysis returned a set of three linear combinations (termed principal components) of these eight soil properties that were responsible for the covariation among the measured variables (i.e., soil properties and disease rating). Component 1 had a significant negative loading value $(-0.97)$ for disease rating, indicating that disease rating was de-emphasized in this component (Table 2). Components 2 and 3 did not have significant loading values (less than an absolute value of 0.12 ) for disease rating. Within component 1 , soil properties with significant positive loadings (boron, 0.79; copper, 0.61; iron, 0.97; soluble magnesium, 0.73; nitrate-nitrogen, 0.91; and percent clay, 0.69) were associated with enhanced biocontrol of take-all by $T$. koningii. Available phosphorus and soil $\mathrm{pH}$ had significant negative loadings in component 1 ( -0.81 and -0.77 , respectively), suggesting that both had an adverse impact on the biocontrol activity of $T$. koningii. In contrast, none of the soil properties that were correlated with take-all disease rating of plants grown in soils with $T$. koningii were correlated with disease rating of control plants. In fact, only sulphate-sulfur was correlated with disease rating of control plants $(R=0.73, P=0.0413)$.

Regression analysis of soil properties associated with biocontrol of take-all by $\boldsymbol{T}$. koningii. The eight soil properties (boron, copper, iron, soluble magnesium, nitrate-nitrogen, percent clay, $\mathrm{pH}$, and available phosphorus) identified with PCF analysis were further analyzed using least squares regression. A four-variable regression model $\left(R^{2}=0.992\right)$ was identified that included nitrate-nitrogen, soil $\mathrm{pH}$, copper, and soluble magnesium to explain the variance in take-all disease rating of wheat treated with T. koningii.

Interactions among soil properties. In addition to the influence of the eight soil properties selected by PCF analysis on takeall biocontrol, significant correlations were also observed among these eight (Table 3). Available phosphorus and soil $\mathrm{pH}$ were positively correlated with each other, but negatively correlated with iron. Boron and soluble magnesium were not correlated with each other, but were both positively correlated with iron and nitratenitrogen. Percent clay was positively correlated with both boron and iron. Copper was positively correlated with soluble magnesium. Nitrate-nitrogen was positively correlated with iron.

TABLE 3. Correlation coefficients among soil properties ${ }^{\mathrm{a}}$

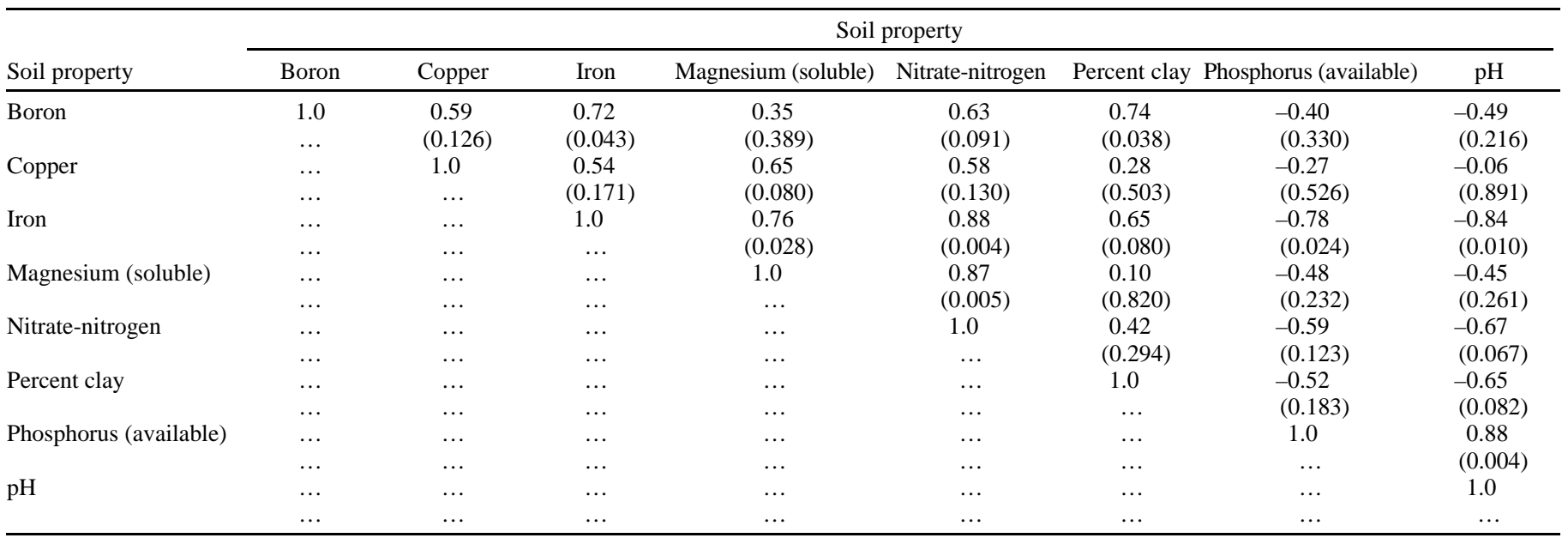

${ }^{\text {a }}$ Positive and negative correlation coefficients with probability values in parentheses. 


\section{DISCUSSION}

T. koningii, originally isolated from a take-all-suppressive soil in Western Australia, reduced take-all severity and increased wheat yield in field trials in South and Western Australia, North Eastern China, and the Pacific Northwest of the United States $(16,32,44)$. However, within a geographic region, the level of control can vary dramatically depending on the site, with little or no control occurring in some fields. We found that under controlled conditions (i.e., temperature, soil moisture, photoperiod, target pathogen density, nontarget pests, and pathogens), the amount of take-all suppression by $T$. koningii varied considerably among eight silt loams representative of the wheat-growing regions of the Pacific Northwest of the United States. Because the soils had been steam-treated to reduce the indigenous microflora, we suggest that variation in the abiotic soil environment was the primary reason for the variable performance of this agent. Furthermore, the fact that disease suppression was not correlated with the conduciveness of a given soil to take-all development suggests that the biocontrol activity of T. koningii, rather than susceptibility of the host or aggressiveness of the pathogen, was influenced by soil factors. Additionally, none of the soil properties evaluated were deficient in the soils included in this study. T. koningii performed similarly in natural and steamtreated soil (16).

An interpretational multivariate statistical procedure, PCF analysis, was applied as a preliminary investigative tool to select soil properties that may influence the biocontrol activity of $T$. koningii. Such information provides a foundation for the development of further hypotheses to determine the role of these properties in biocontrol. We identified a negative interrelationship between boron, copper, iron, soluble magnesium, nitrate-nitrogen, percent clay, and take-all severity in the presence of $T$. koningii in these eight silt loams. In contrast, take-all severity was positively interrelated with soil $\mathrm{pH}$ and available phosphorus in the presence of $T$. koningii. In other words, the biocontrol agent was most effective, for example, in soils with higher iron or clay content and in soils with a lower $\mathrm{pH}$ or available phosphorus concentration. No significant influence on the biocontrol activity of T. koningii was found for the other 13 parameters that were considered. A three-component solution using these eight variables accounted for about $95 \%$ of the variation in disease rating in soils treated with $T$. koningii. A regression model was developed that included the soil variables boron, copper, iron, and nitrate-nitrogen. A similar approach has been used to identify edaphic parameters positively (e.g., ammonium-nitrogen, zinc, or soil $\mathrm{pH}$ ) and negatively (e.g., iron, total nitrogen, percent clay, sand, or organic matter) interrelated with the biocontrol activity of a bacterial agent, P. fluorescens strain 2-79 (29). Bashan et al. (2) applied PCF analysis to demonstrate that survival of the dinitrogenfixing rhizobacterium Azospirillum brasilense in 23 soils from Mexico and Israel was positively interrelated with percent clay, nitrogen, organic matter, and water-holding capacity, and negatively interrelated with percentages of calcium-carbonate and fine and rough sand.

An exceptional diversity of mechanisms contribute to the biocontrol activity of Trichoderma spp. including the production of antibiotics, volatiles, and lytic enzymes; mycoparasitism and competitiveness in the rhizosphere; bulk soil; or crop residue $(4,18,22$, $31,38)$. While each of these has been proposed in different reports to be primarily responsible for biocontrol, the relative importance of individual mechanisms more likely fluctuates depending on the strain, environmental conditions, and pathosystem. At any stage in early disease development, soil factors can directly or indirectly affect the expression by Trichoderma of one or more biocontrol mechanisms. The few published reports that describe effects of edaphic factors on various facets of the biology and ecology of Trichoderma spp. may provide clues of how the factors identified in this study influenced biocontrol. For example, low soil $\mathrm{pH}$ $(\mathrm{pH}<7)$ has long been known to favor indigenous populations of antagonistic Trichoderma spp. and to favor Trichoderma-mediated suppression of a diversity of soilborne pathogens including G. graminis var. tritici $(4,7,31,38)$. Harman and Taylor (21) have shown that acidification of the soil and seed environment can improve the competitiveness and biocontrol activity of introduced Trichoderma strains. Acidic conditions may enhance conidia production and germination $(5,10,35)$, mycelial growth (20), and production and activity of antimicrobial compounds such as antibiotics and lytic enzymes $(5,12)$. Alkaline soils tend to evolve more ammonia than acidic soils, which reduces germination of Trichoderma conidia and has been suggested to reduce the biocontrol activity of T. hamatum (31). Cellulase production by $T$. koningii, which is associated with competitive saprophytic ability and rhizosphere and spermosphere competence $(1,9)$, was negatively correlated with soil $\mathrm{pH}(47)$.

Mineral nutrition is essential for growth and, within a narrower range, stimulatory of fungal secondary metabolism (19). High total nitrogen availability increased sporulation, production of antifungal anthroquinone pigments, hyphal growth rate (17), and antagonistic activity of Trichoderma spp. against the wood rot fungus Serpula lacrymans (36). Soil nitrate levels were positively correlated with cellulase production (47) and may favor competitiveness of the biocontrol agent with the pathogen. Magnesium increased growth of $T$. viridae (37), and copper enhanced conidiogenesis and biomass nitrogen in other hyphomycetes $(25,27)$. At slightly higher concentrations, minerals such as copper can inhibit the production of certain secondary metabolites and have toxic effects that may be more acute for the pathogen than for the antagonist (19). While clay minerals have been reported to reduce respiration of $T$. viridae, an indicator of fungal activity, kaolinite had little negative impact on respiration even at concentrations of $40 \%$ (43). In contrast, montmorillonite reduced respiration by more than half, at concentrations lower than $4 \%$. This demonstrates that clay type is probably more critical than total clay content.

Interactions between soil factors affect the biological availability of elements and overall soil quality, which may be as important in biocontrol as any direct effect of soil factors on Trichoderma activity or pathogen vulnerability. Both positive and negative correlations were observed among the eight soil properties that had been selected by PCF as having an influence on biocontrol in our study. Acidic soil $\mathrm{pH}$ increases the availability of certain macroand microelements including boron and iron, but reduces the availability of others including phosphorus (3). Soluble phosphates are increasingly complexed with increasing activity of iron, manganese, and other metal ions under conditions of soil acidification (3). Copper, which was positively correlated with biocontrol, has been reported to reduce fungal accumulation of phosphorus (25), which was negatively correlated with biocontrol in this study. Phosphorus, in turn, can interfere with manganese availability, leading to increased take-all susceptibility of wheat (24).

The proportion of soil textural components such as clays has a major influence on water flow, oxygen availability, and the matrix for fungal growth and dispersal. Certain types of clay minerals may benefit biocontrol activity by increasing the availability of iron, magnesium, and other essential elements, a hypothesis that is underscored by the observation that soil amendments of iron chelates reduce proliferation of Trichoderma (31). In soils with an active indigenous microbial community, clay minerals may contribute to biocontrol by adsorbing bacterial iron chelators and other antifungal compounds (34) that may be more efficient than those produced by Trichoderma and have an inhibitory effect on growth of the biocontrol agent (23).

In our analysis, soil factors were not ranked according to importance. Given the complexity of mechanisms involved in biocontrol and sundry interactions between soil parameters, the influence of a factor probably depends on the prevailing cropping conditions and on the stage of crop growth at which biocontrol occurs. For example, nitrate fertilizers tend to increase take-all, in part, because they raise rhizosphere $\mathrm{pH}$, which is favorable to the pathogen and 
unfavorable for the biocontrol agent (38). Although this seems contradictory to our finding that nitrate-nitrogen levels were positively correlated with $T$. koningii biocontrol activity, it suggests that pathogen suppression in the bulk soil with an acidic $\mathrm{pH}$ that is less affected by nitrates (42) may have been a major component of biocontrol during early plant growth, and other factors may have become more important as biocontrol shifted to the infection court in the rhizosphere. Extreme levels of one factor may offset the influence of another. Recently, T. koningii was evaluated for takeall biocontrol in field trials at four sites in China (44). A field site in Chuzhou, Anhui Province, that had the lowest soluble phosphorus content $(35.3 \mathrm{mg} / \mathrm{kg})$ of the four soils supported the highest level of take-all biocontrol, despite the fact that this soil was the most alkaline ( $\mathrm{pH}$ 7.5). In contrast, no control was observed at Yantai, Shangdong Province, which had a lower $\mathrm{pH}$ (5.7) but a much higher phosphorus content $(297.5 \mathrm{mg} / \mathrm{kg})$, suggesting that at these sites phosphorus content may have been more critical than $\mathrm{pH}$. Other parameters (e.g., boron, iron, and nitrate-nitrogen) not presented by Tang et al. (44) may have further balanced unfavorable soil $\mathrm{pH}$ and phosphorus concentrations.

Understanding which abiotic soil factors have the most influence on the biocontrol activity of $T$. koningii and how these factors interact may provide clues to biocontrol mechanisms and their regulation in situ. For example, Ownley et al. (29) demonstrated that zinc was positively interrelated with the biocontrol activity of $P$. fluorescens 2-79, and this trace mineral was subsequently shown to enhance the production of phenazine antibiotics essential for disease suppression (39), further supporting evidence that antibiosis is the primary biocontrol mechanism with this bacterial agent (45, 46). With T. koningii, however, the principle mechanism(s) of suppression remains uncertain, and investigations are warranted to elucidate the influence the soil factors, determined in this study to be associated with biocontrol (e.g., iron, $\mathrm{pH}$, boron, copper, and soluble magnesium), have on production of antifungal compounds by $T$. koningii and competition with the pathogen. Another practical application of our work may be the development of formulations amended with factors favorable to the activity of the biocontrol agent. Acidifying cucumber seeds with $\mathrm{HCl}$ to $\mathrm{pH} 3.7$ when applying T. harzianum inoculant improved the level of protection against Pythium damping-off compared with the biocontrol agent alone (21), and adding zinc to a soil low in zinc improved the biocontrol activity of $P$. fluorescens 2-79 in that soil (46). Amendments should be designed to selectively deliver microelements or $\mathrm{pH}$ changes to the biocontrol agent to optimize availability to the target agent, avoid negative impacts on other beneficial organisms or the host, and avoid increasing disease.

Understanding the effect of soil factors on biocontrol agents also facilitates treatment customization, selecting strains to be applied at sites where the soil environment is predictive of effective performance (6). Our analysis suggested that $T$. koningii should be more effective in a Puget silt loam at Mt. Vernon, WA, because this soil has more boron, nitrate-nitrogen, soluble magnesium, copper, iron, percent clay, lower $\mathrm{pH}$, and less available phosphorus, all favorable for biocontrol, and that $T$. koningii would be less effective in a Thatuna silt loam at Pullman, WA, which has less favorable levels of all these factors. When the performance of $T$. koningii was evaluated in field trials, as predicted by our analysis, wheat yield was consistently increased at Mt. Vernon as a result of take-all suppression, while biocontrol was less effective and more variable at the Pullman site (16). Mixing biocontrol agents is a promising approach to improve the level and consistency of disease suppression and would be a logical extension of customized treatments. Some of the key soil factors favorable to Trichoderma (e.g., low $\mathrm{pH}$ and high iron) contrast those factors that are favorable to fluorescent pseudomonads (e.g., high $\mathrm{pH}$ and low iron). Provided that the fungal and bacterial agents are compatible in the field (16), mixtures of such diverse biocontrol agents may provide control across a wider range of soil types.

\section{ACKNOWLEDGMENTS}

We are especially grateful to the late A. Simon for generously sharing both the strain of T. koningii used in our studies and his unique understanding of this biocontrol agent. We thank M. Gano-Smith and R. Reeder for technical support and M. Ryder for critical evaluation of the manuscript prior to journal submission.

\section{LITERATURE CITED}

1. Ahmad, J. S., and Baker, R. 1987. Competitive saprophytic ability and cellulolytic activity of rhizosphere-competent mutants of Trichoderma harzianum. Phytopathology 77:358-362.

2. Bashan, Y., Puente, M. E., Rodriguez-Mendoza, M. N., Toledo, G., Holguin, G., Ferrera-Cerrato, R., and Pedrin, S. 1995. Survival of Azospirillum brasilense in the bulk soil and rhizosphere of 23 soil types. Appl. Environ. Microbiol. 61:1938-1945.

3. Brady, N. C. 1984. The Nature and Properties of Soils. Macmillan Publishing Co., New York.

4. Chet, I. 1987. Trichoderma-Application, mode of action, and potential as a biocontrol agent of soilborne plant pathogenic fungi. Pages 137-160 in: Innovative Approaches to Plant Disease Control. I. Chet, ed. John Wiley \& Sons, New York.

5. Chet, I., and Baker, R. 1980. Induction of suppressiveness to Rhizoctonia solani in soil. Phytopathology 70:994-998.

6. Cook, R. J. 1993. Making greater use of introduced microorganisms for biological control of plant pathogens. Annu. Rev. Phytopathol. 31:53-80.

7. Cook, R. J., and Baker, K. F. 1983. The Nature and Practice of Biological Control of Plant Pathogens. The American Phytopathological Society, St. Paul, MN.

8. Cook, R. J., and Weller, D. M. 1987. Management of take-all in consecutive crops of wheat or barley. Pages 41-76 in: Innovative Approaches to Plant Disease Control. I. Chet, ed. John Wiley \& Sons, New York.

9. Cotes, A. M., Lepoivre, P., and Semal, J. 1996. Correlation between hydrolytic enzyme activity measured in bean seedlings after Trichoderma koningii treatment combined with pregermination and the protective effect against Pythium splendens. Eur. J. Plant Pathol. 102:497-506.

10. Danielson, R. M., and Davey, C. B. 1973. Effects of nutrients and acidity on phialospore germination of Trichoderma in vitro. Soil Biol. Biochem. 5:517-524.

11. Défago, G., Berling, C. H., Burger, U., Haas, D., Kahr, G., Keel, C., Voisard, C., Wirthner, P., and Wüthrich, B. 1990. Suppression of black root rot of tobacco and other root diseases by strains of Pseudomonas fluorescens: Potential applications and mechanisms. Pages 93-108 in: Biological Control of Soil-borne Plant Pathogens. D. Hornby, R. J. Cook, Y. Henis, W. H. Ko, A. D. Rovira, B. Schippers, and P. R. Scott, eds. CAB International, Wallingford, United Kingdom.

12. Dennis, C., and Webster, J. 1971. Antagonistic properties of speciesgroups of Trichoderma. I. The production of non-volatile antibiotics. Trans. Br. Mycol. Soc. 57:25-39.

13. Dewan, M. M., and Sivasithamparam, K. 1988. Identity and frequency of occurrence of Trichoderma spp. in roots of wheat and rye-grass in Western Australia and their effects on root rot caused by Gaeumannomyces graminis var. tritici. Plant Soil 109:93-101.

14. Duffy, B. K., and Défago, G. 1995. Influence of cultural conditions on spontaneous mutations in Pseudomonas fluorescens CHA0. (Abstr.) Phytopathology 85:1146.

15. Duffy, B. K., and Défago, G. 1996. Influence of minerals, C-source, and $\mathrm{pH}$ on antibiotic and salicylate production by Pseudomonas fluorescens biocontrol strain CHA0. (Abstr.) Phytopathology 86:S79.

16. Duffy, B. K., Simon, A., and Weller, D. M. 1996. Combination of Trichoderma koningii with fluorescent pseudomonads for control of take-all on wheat. Phytopathology 86:188-194.

17. Fargasova, A. 1992. The influence of various nitrogen sources on the growth, conidiation and pigmentation production of the brown mutant of Trichoderma viridae M-108. Biologia 47:453-464.

18. Ghisalberti, E. L., and Sivasithamparam, K. 1991. Antifungal antibiotics produced by Trichoderma spp. Soil Biol. Biochem. 23:1011-1020.

19. Griffin, D. H. 1994. Fungal Physiology, 2nd ed. John Wiley \& Sons, New York

20. Hadar, Y., Harman, G. E., and Taylor, A. G. 1984. Evaluation of Trichoderma koningii and T. harzianum from New York soils for biological control of seed rot caused by Pythium spp. Phytopathology 74:106-110.

21. Harman, G. E., and Taylor, A. G. 1988. Improved seedling performance by integration of biological control agents at favorable $\mathrm{pH}$ levels with solid matrix priming. Phytopathology 78:520-525.

22. Huang, Q., Tezuka, Y., Kikuchi, T., Nishi, A., Tubaki, K., and Tanaka, K. 1995. Studies on metabolites of mycoparasitic fungi. II. Metabolites of Trichoderma koningii. Chem. Pharm. Bull. 43:223-229. 
23. Hubbard, J. P., Harman, G. E., and Hadar, Y. 1983. Effect of soilborne Pseudomonas spp. on the biological control agent, Trichoderma hamatum, on pea seeds. Phytopathology 73:655-659.

24. Huber, D. M. 1989. The role of nutrition in the take-all disease of wheat and other small grains. Pages 46-74 in: Soilborne Plant Pathogens: Management of Diseases with Macro- and Microelements. A. W. Engelhard, ed. The American Phytopathological Society, St. Paul, MN.

25. Ismail, I. M. K., Abdel-Rahman, T. M. A., Ali, M. I. A., and Sharaf, E. F. 1991. Effect of zinc and copper on metabolic activities of some fungi. Egypt. J. Microbiol. 26:1-13.

26. Kim, J.-O., and Mueller, C. W. 1978. Introduction to Factor Analysis: What It Is and How to Do It. Sage Publications, Beverly Hills, CA.

27. King, A. D., Charley, N. J., Flores, M., Hocking, A. D., and Royer, C. 1992. Effect of copper concentration in growth media on conidiation in Aspergillus and Penicillium. Pages 337-339 in: Modern Methods in Food Mycology. R. A. Samson, A. D. Hocking, J. I. Pitt, and A. D. King, eds. Elsevier Science Publishers, Amsterdam.

28. Ott, L. 1988. An Introduction to Statistical Methods and Data Analysis, 3rd ed. PWS-KENT Publishing Co., Boston.

29. Ownley, B. H., Weller, D. M., and Alldredge, J. R. 1991. Relation of soil chemical and physical factors with suppression of take-all by Pseudomonas fluorescens 2-79. Pages 299-301 in: Plant Growth-Promoting Rhizobacteria-Progress and Prospects. C. Keel, B. Koller, and G. Défago, eds. IOBC/WPRS (Int. Organ. Biol. Integrated Control Noxious Anim. Plants/West Palaearctic Regional Sect.) Bull. 14.

30. Ownley, B. H., Weller, D. M., and Thomashow, L. S. 1992. Influence of in situ and in vitro $\mathrm{pH}$ on suppression of Gaeumannomyces graminis var. tritici by Pseudomonas fluorescens 2-79. Phytopathology 82:178-184.

31. Papavizas, G. C. 1985. Trichoderma and Gliocladium: Biology, ecology, and potential for biocontrol. Annu. Rev. Phytopathol. 23:23-54.

32. Rovira, A., Ryder, M., and Harris, A. 1992. Biological control of root diseases with pseudomonads. Pages 175-184 in: Biological Control of Plant Diseases-Progress and Challenges for the Future. E. S. Tjamos, G. C. Papavizas, and R. J. Cook, eds. Plenum Press, New York.

33. Sarniguet, A., Lucas, P., Lucas, M., and Samson, R. 1992. Soil conduciveness to take-all of wheat: Influence of the nitrogen fertilizers on the structure of populations of fluorescent pseudomonads. Plant Soil 145:29-36.

34. Schippers, B., Bakker, A. W., and Bakker, P. A. H. M. 1987. Interactions of deleterious and beneficial rhizosphere microorganisms and the effect of cropping practices. Annu. Rev. Phytopathol. 25:339-358.

35. Schüepp, H., and Frei, E. 1969. Soil fungistasis with respect to $\mathrm{pH}$ and profile. Can. J. Microbiol. 15:1273-1279.

36. Score, A. J., and Palfreyman, J. W. 1994. Biological control of the dry rot fungus Serpula lacrymans by Trichoderma species: The effects of complex and synthetic media on interaction and hyphal extension rates. Int. Biodeterior. Biodegrad. 33:115-128.

37. Shukla, D. D., and Mishra, A. 1970. Effects of salts on growth of Trichoderma viridae. Friesia 9:299-301.

38. Simon, A., and Sivasithamparam, K. 1989. Pathogen-suppression: A case study in biological suppression of Gaeumannomyces graminis var. tritici in soil. Soil Biol. Biochem. 21:331-337.

39. Slininger, P. J., and Jackson, M. A. 1992. Nutritional factors regulating growth and accumulation of phenazine 1-carboxylic acid by Pseudomonas fluorescens 2-79. Appl. Microbiol. Biotechnol. 37:388-392.

40. Slininger, P. J., and Shea-Wilbur, M. A. 1995. Liquid-culture pH, temperature, and carbon (not nitrogen) source regulate phenazine productivity of the take-all biocontrol agent Pseudomonas fluorescens 2-79. Appl. Microbiol. Biotechnol. 43:794-800.

41. Smiley, R. W. 1978. Antagonists of Gaeumannomyces graminis from the rhizoplane of wheat in soils fertilized with ammonium- or nitrate-nitrogen. Soil Biol. Biochem. 10:169-174.

42. Smiley, R. W., and Cook, R. J. 1973. Relationship between take-all of wheat and rhizosphere $\mathrm{pH}$ in soils fertilized with ammonium vs. nitratenitrogen. Phytopathology 63:882-890.

43. Stotzky, G., and Rem, L. T. 1967. Influence of clay minerals on microorganisms. IV. Montmorillonite and kaolinite on fungi. Can. J. Microbiol. 13:1535-1550.

44. Tang, W., Gao, J., Yang, H., Luo, D., Yan, Z., Mei, R., Ryder, M., and Rovira, A. 1996. Seed treatment by microorganisms for control of takeall and sharp eyespot of wheat in field trials in China. Pages 38-43 in: Advances in Biological Control of Plant Diseases. W. Tang, R. J. Cook, and A. Rovira, eds. China Agricultural University Press, Beijing.

45. Weller, D. M. 1988. Biological control of soilborne plant pathogens in the rhizosphere with bacteria. Annu. Rev. Phytopathol. 26:379-407.

46. Weller, D. M., and Thomashow, L. S. 1994. Current challenges in introducing beneficial microorganisms into the rhizosphere. Pages 1-18 in: Molecular Ecology of Rhizosphere Microorganisms: Biotechnology and the Release of GMO's. F. O'Gara, D. N. Dowling, and B. Boesten, eds. $\mathrm{VCH}$, Weinheim, Germany.

47. Widden, P., Cunningham, J., and Breil, B. 1988. Decomposition of cotton by Trichoderma species: Influence of temperature, soil type, and nitrogen levels. Can. J. Microbiol. 35:469-473. 